\title{
Comparative Study of Cigarette Smoke Cytotoxicity Using Two In Vitro Assay Systems*
}

\author{
by \\ Toshiro Fukushima, Hitomi Tanaka, Takeshi Yamamoto \\ Product Science Division, R\&D Group, Japan Tobacco Inc., 6-2 Umegaoka, Aoba-ku, Yokohama, Kanagawa 227-8512, \\ Japan
}

\section{SUMMARY}

The aim of this study was to compare the results obtained from two in vitro cytotoxicity assays that depend upon different mechanisms/modes of action. The Neutral Red Uptake (NRU) assay is based on endocytotic activity whereas the Water Soluble Tetrazolium Salts (WST-1) assay is based on mitochondrial dehydrogenase activity. Both were investigated in light of their wide use and documented validation. The total particulate matter (TPM) and gas vapor phase (GVP) of main stream smoke derived from Kentucky reference cigarettes $3 \mathrm{R} 4 \mathrm{~F}$ and 10 test cigarettes made of $100 \%$ flue-cured or $100 \%$ Burley tobacco were individually applied to the two assays using CHO-K1 cells. In addition, cigarette smoke constituents and known cytotoxic agents, documented to affect specific endpoints, were evaluated within both assays. Although the NRU assay was primarily more sensitive than the WST-1 assay, both assays provided comparable results in terms of the rank order for the cytotoxicity of cigarette smoke samples. In addressing the cytotoxicity of constituents in cigarette smoke, acrolein, hydroquinone and catechol gave clear dose-related decreases in cell viability (an end point common in both assays). Moreover, enzyme inhibitors of the mitochondrial respiratory chain and chemicals causing membrane disruption also showed similar responses regardless of the specific endpoint addressed within the cytotoxicity assay. In conclusion, results from the NRU and WST-1 assay are comparable therefore indicating results were independent of the different assay detection mechanisms/modes of action. [Beitr. Tabakforsch. Int. 26 (2014) 98-108]

\section{ZUSAMMENFASSUNG}

Ziel der Studie war ein Vergleich der Ergebnisse aus zwei In-vitro-Zytotoxizitätsbestimmungen, die auf unterschiedlichen Mechanismen/Wirkungsweisen basieren. Der
Neutralrot-Test (NRU) basiert auf endozytotischer Aktivität, während der WST-1-Assay (Water Soluble Tetrazolium Salts) auf der Dehydrogenaseaktivität der Mitochondrien beruht. Beide wurden aufgrund ihrer breiten Verwendung und dokumentierten Validierung untersucht. Die Gesamtpartikelmasse (TPM) und Gas/Dampfphase (GVP) des Hauptstromrauchs aus Kentucky-Referenzzigaretten 3R4F und 10 Testzigaretten, bestehend aus 100\% heißluftgetrocknetem Tabak oder 100\% Burleytabak, wurden jeweils unter Verwendung von CHO-K1-Zellen den beiden Tests unterzogen. Darüber hinaus wurden in beiden Tests Zigarettenrauchbestandteile und bekannte zytotoxische Substanzen, von denen dokumentiert ist, dass sie bestimmte Endpunkte beeinflussen, untersucht. Auch wenn der NRU-Test primär empfindlicher war als der WST-1-Assay, lieferten beide Tests vergleichbare Ergebnisse hinsichtlich der Rangordnung der Zytotoxizität von Zigarettenrauchproben. In Bezug auf die Zytotoxizität der Bestandteile von Zigarettenrauch führten Acrolein, Hydrochinon und Katechol zu klaren dosisabhängigen Abnahmen der Zellviabilität (ein Endpunkt bei beiden Tests). Auch Enzyminhibitoren der mitochondrialen Atmungskette und Chemikalien, die eine Membranruptur verursachen, zeigten ähnliche Reaktionen unabhängig von den spezifischen Endpunkten, die in der Zytotoxizitätsbestimmung betrachtet wurden. Zusammengefasst waren die Ergebnisse aus dem NRU-Test und dem WST-1-Assay vergleichbar. Dieses deutet darauf hin, dass die Ergebnisse von den unterschiedlichen Bestimmungsmechanismen/ Wirkungsweisen unabhängig waren. [Beitr. Tabakforsch. Int. 26 (2014) 98-108]

\section{RESUME}

L'objet de la présente étude fut de comparer les résultats obtenus à partir de deux essais de cytotoxicité in vitro s'appuyant sur des mécanismes/modes d'action différents. Le test de fixation du rouge neutre (Neutral Red Uptake - 
NRU) se fonde sur l'endocytose tandis que le test des sels de tetrazolium hydrosolubles (WST-1) s'appuie sur l'activité de la déshydrogénase mitochondriale. Ces deux tests furent analysés à la lumière de leur fréquence d'utilisation et de leur validation documentée. La matière particulaire totale (MPT) et la phase gaz/vapeur (PGV) de la fumée principale produite par les cigarettes de référence Kentucky 3R4F et les dix cigarettes testées composées à $100 \%$ de tabac Burley ou à $100 \%$ de tabac jaune furent appliquées individuellement dans les deux essais utilisant des cellules CHO-K1. En outre, les constituants de fumée de cigarette et les agents cytotoxiques connus, dont la capacité à affecter certains indicateurs de résultat est documentée, furent évalués lors des deux tests. Bien que le test de fixation du rouge neutre se révéla, dans un premier temps, plus sensible que le test aux WST-1, les deux essais livrèrent des résultats comparables en termes de classement par ordre de rang de la cytotoxicité des échantillons de fumée de cigarette. Eu égard à la cytotoxicité des constituants de fumée de cigarette, l'acroléine, l'hydroquinone et la catéchine présentèrent de claires diminutions de viabilité cellulaire proportionnelles à la dose (un indicateur de résultat commun aux deux essais). Par ailleurs, les inhibiteurs enzymatiques de la chaîne respiratoire mitochondriale et les produits chimiques portant atteinte à la membrane cellulaire présentèrent également des réactions similaires, indépendamment de l'indicateur de résultat spécifique visé lors du test de cytotoxicité. En conclusion, les résultats glanés lors du test de fixation du rouge neutre et du test aux sels de tetrazolium hydrosolubles sont comparables et les résultats indiqués ne dépendirent donc nullement des mécanismes/modes d'action de détection des différents essais. [Beitr. Tabakforsch. Int. 26 (2014) 98-108]

\section{INTRODUCTION}

Cytotoxicity is regarded as an important step in the process of irritation, inflammation, cell hyperplasia and oxidative stress. These biological events are also thought to play a role in chronic diseases (1-3). In light of this, in vitro cytotoxicity assays are widely used by a variety of researchers and industrial fields for characterizing the potential of test substances to be used as food additives, pesticides, cosmetics or pharmacological agents for possible hazards to human health. Cytotoxicity assays are also considered to be a useful tool in the estimation of in vivo starting doses for acute oral systemic toxicity tests. This approach results in reducing and replacing the use of laboratory animals in experiments. The scientific validity and usefulness of cytotoxicity assays in hazard characterization is supported by extensive research that indicates a good correlation between in vitro cytotoxicity and acute lethality as well as irritancy potential (4-7). Regarding cigarette smoke, the relationship between in vitro cytotoxicity and acute inhalation lethality does not exist, as the carbon monoxide and probably nicotine concentration in the smoke is the factor determining acute lethality (8). However, it can be assumed that in vitro cytotoxicity correlates with the irritative activity and inflammatory responses in the smoker's respiratory tract, associated with smoking related diseases (9-11).

It is well known that cigarette smoke is a complex mixture of more than 5000 compounds including those which are both mutagenic and cytotoxic $(1,12,13)$. Various in vitro studies have indicated that cigarette smoke contributes to a wide variety of toxic and biologically relevant responses (14-17). Hence, for the tobacco industry, these in vitro assays have been useful for assessing the potential relative toxicity of cigarette smoke from new products with different specifications or different tobacco materials (18-21). The task force of in vitro toxicity testing in Cooperation Centre for Scientific Research Relative to Tobacco (CORESTA) recommends the Neutral Red Uptake (NRU) assay as a valuable tool for the assessment of cigarette smoke cytotoxicity (22).

There are however a variety of assays addressing different cytotoxic endpoints, e.g., cell proliferation inhibition, enzymatic inhibition and cell membrane damage that have been well-established. As such, it has been reported that a more reliable result may be obtained in a toxicity assessment by combining several assays with the capability of detecting different endpoints/mechanisms of action in each individual in vitro test $(11,23,24)$. However, the benefit of a combinational assessment using multiple cytotoxicity assays is not clear as very little information exists concerning the comparison between the results from different assay systems.

Thus, in order to examine the specificity of the results produced from different cytotoxicity assays based on specific detection mechanisms, the NRU assay and WST-1 assay were utilized in this present study. The NRU assay is based on the uptake and lysosomal accumulation of the supravital dye, neutral red (25), whereas the WST-1 assay is based on the reduction of the red WST-1 tetrazolium salt to the yellow formazan product by mitochondrial succinate dehydrogenase (26). These methods have a very high level of standardization and validation, and have also been well documented for the assessment of cigarette smoke cytotoxicity. In this study, cigarette smoke fractions and some substances acting at a specific endpoint within these assays were used to establish a comparison between assay results in terms of dose response and rank order of cytotoxicities between the different test samples.

\section{MATERIALS AND METHODS}

\section{Cigarette smoke samples}

Kentucky reference cigarettes, 3R4F, manufactured by Kentucky Tobacco Research and Development Center were purchased from an import agent in Japan (Sanyo Trading Co., Ltd., Tokyo, Japan). Test cigarettes were produced as $100 \%$ flue-cured or $100 \%$ Burley tobacco with a non-ventilated cellulose acetate filter (Table 1). The single grade tobaccos were selected from a wide variety of leaf positions and production areas so that the component composition varies among the test cigarettes. Cigarettes were conditioned for at least 48 hours at $22 \pm 0.5{ }^{\circ} \mathrm{C}$ and $60 \pm 3 \%$ relative humidity according to ISO standard 3402 (27). Before smoking, except for $3 \mathrm{R} 4 \mathrm{~F}$, the cellulose acetate in the filter part was removed from the cigarettes to 
Table 1. Test cigarettes were smoked without cellulose acetate filter according to ISO smoking regime.

\begin{tabular}{l|c|c|c|c}
\hline Cigarette code & Type & $\begin{array}{c}\text { Tobacco weight } \\
(\mathrm{g})\end{array}$ & $\begin{array}{c}\text { TPM yield } \\
\text { (mg/cigarette) }\end{array}$ & $\begin{array}{c}\text { Puff count } \\
\text { (puff/cigarette) }\end{array}$ \\
\hline FC-1 & Flue-cured & 0.75 & 40.6 & 9.2 \\
FC-2 & Flue-cured & 0.71 & 37.9 & 7.8 \\
FC-3 & Flue-cured & 0.68 & 28.6 & 6.9 \\
FC-4 & Flue-cured & 0.85 & 46.0 & 10.6 \\
FC-5 & Flue-cured & 0.80 & 39.4 & 9.0 \\
BLY-1 & Burley & 0.64 & 32.0 & 6.5 \\
BYL-2 & Burley & 0.62 & 26.5 & 5.2 \\
BLY-3 & Burley & 0.58 & 21.8 & 4.8 \\
BLY-4 & Burley & 0.56 & 17.6 & 4.8 \\
BLY-5 & Burley & 0.55 & 17.8 & \\
\hline
\end{tabular}

yield more TPM during machine smoking. Cigarettes were smoked using an automatic smoking machine (RM200, Borgwaldt $\mathrm{KC} \mathrm{GmbH}$, Hamburg, Germany) under ISO smoking regime following ISO standard 3308, i.e., $35 \mathrm{~mL}$ puff, 2 sec puff duration, 60 sec puff interval, with the ventilation holes unblocked (28). The TPM was collected on a Cambridge filter pad (Borgwaldt $\mathrm{KC} \mathrm{GmbH}$, Hamburg, Germany), which was then extracted with dimethyl sulfoxide (DMSO, Wako Pure Chemical Industries, Ltd., Osaka, Japan) to achieve final concentrations of $10 \mathrm{mg} / \mathrm{mL}$ for the assay. The TPM solutions were dispended into amber vials in small quantities and kept frozen below $-70{ }^{\circ} \mathrm{C}$ until just before use in the assays. Gas vapor phase (GVP) which passed through the filter pad was collected by bubbling into phosphate buffer saline (PBS, Sigma-Aldrich, K.K.. Tokyo, Japan) in an impinger into ice bath containing ice and water. The concentration of the GVP sample was expressed on a per mg TPM unit based on the yield of the TPM concurrently collected on the Cambridge filter pad. After the smoking session, the sample solution was diluted with cooled PBS to give a $6 \mathrm{mg}$ TPM weight equivalent $/ \mathrm{mL}$ solution. The GVP sample was used in the assay within 1 hour after the completion of smoking. Two independent samples were collected for each cigarette.

\section{Chemicals}

In order to investigate the contribution of several smoke constituents on the cytotoxicity of cigarette smoke, in the NRU assay and WST-1 assay chemicals were selected from reference compounds specified in the Canadian regulation and listed as harmful and potentially harmful smoke constituents by U.S. Food and Drug Administration (29, 30). Eight individual and five mixtures of the compounds deemed to be of similar structure were prepared as a DMSO solution. The concentrations of each solution for the individual as well as the mixtures were calculated on a per mg TPM unit based on laboratory data for the chemical analysis of the 3R4F (Table 2). The composition of the compounds in the mixture was determined according to analytical data.

In addition, the cytotoxicity of reference chemicals known to act on a specific endpoint within both assays was determined to confirm whether the damage associated with a specific endpoint was reflected in the assay results. For this purpose malonic acid (Tokyo Chemical Industries Co., Ltd., Tokyo, Japan) and chlorpromazine (Wako Pure Chemical Industries, Ltd., Tokyo, Japan) were selected as mitochondrial enzyme inhibitors $(31,32)$. Sodium dodecyl sulfate (SDS, Sigma-Aldrich, K.K.. Tokyo, Japan) and benzethonium chloride (Wako Pure Chemical Industries, Ltd., Osaka, Japan) were selected as documented membrane-disrupting surfactants (33). These substances were dissolved in DMSO and final concentrations were adjusted to be appropriate to ensure the establishment of a dose-response curve for later evaluation.

\section{Cell culture}

The assays in this study were performed using Chinese Hamster Ovary (CHO-K1) cells purchased from Japanese Collection of Research Bioresources Cell Bank (Osaka, Japan). Cell culture was maintained with Ham's F12 medium (Invitrogen Japan K.K., Tokyo, Japan) supplemented with 10\% fetal bovine serum (Invitrogen Japan K.K., Tokyo, Japan) in an incubator at $37^{\circ} \mathrm{C}$ and $5 \% \mathrm{CO}_{2}$ in air and repeatedly sub cultured to prevent overgrowth. The cell culture from passage 3 to passage 30 was used for the assays.

\section{NRU assay}

CHO-K1 cells (200 $\mu \mathrm{L}$ of $5 \times 10^{4}$ cells $\left./ \mathrm{mL}\right)$ were seeded into 96-well tissue culture plates to achieve approximately $70 \%$ confluency at the end of pre-culture for 24 hours. After the pre-culture, the culture medium was replaced with the exposure medium including cigarette smoke sample or test chemical. After consecutive incubation for 24 hours, the exposure medium was removed and then $200 \mu \mathrm{L}$ of the medium including $22 \mu \mathrm{g} / \mathrm{mL}$ of neutral red dye (Sigma-Aldrich Co. K.K.. Tokyo, Japan) was added to the well. After the incubation for 3 hours, cells were fixed with $200 \mu \mathrm{L}$ of $1 \% \mathrm{CaCl}_{2}$ (Wako Pure Chemical Industries, Ltd., Osaka, Japan) aqueous solution including $1 \%$ formalin (Wako Pure Chemical Industries, Ltd., Osaka, Japan) for $3 \mathrm{~min}$. The neutral red dye was extracted with $100 \mu \mathrm{L}$ of $1 \%$ acetic acid (Wako Pure Chemical Industries, Ltd., Osaka, Japan) aqueous solution including $50 \%$ ethanol and shaken at $800 \mathrm{rpm}$ for $10 \mathrm{~min}$. The absorbance was measured at $540 \mathrm{~nm}$ using a microplate reader (Model 680 Microplate Reader, Bio-Rad Laboratories, Inc., Hercules, CA, USA). 
Table 2. Yield of smoke constituents from 3R4F cigarettes, smoked under ISO smoking regime. Samples prepared as the individual smoke constituents and their mixtures for cytotoxicity assays.

\begin{tabular}{|c|c|c|c|c|}
\hline Smoke constituents & & $\begin{array}{c}\text { Yield } \\
\text { (ng/mg TPM equivalent) } \\
\end{array}$ & $\begin{array}{l}\text { Individual } \\
\text { Sample \# }\end{array}$ & $\begin{array}{c}\text { Mixture } \\
\text { Sample \# }\end{array}$ \\
\hline \multirow[t]{4}{*}{ Tobacco-specific nitrosoamines (TSNA) } & $\mathrm{NNN}^{\text {a) }}$ & 13.0 & & 9 \\
\hline & NAT ${ }^{\text {a) }}$ & 11.1 & & 9 \\
\hline & $N A B^{\text {a) }}$ & 1.45 & & 9 \\
\hline & $\mathrm{NNK}^{\text {a) }}$ & 11.2 & & 9 \\
\hline \multirow[t]{8}{*}{ Carbonyls } & Formaldehyde & 1660 & & 10 \\
\hline & Acetaldehyde & 51100 & & 10 \\
\hline & Acetone & 20000 & & 10 \\
\hline & Acrolein & 4840 & 1 & 10 \\
\hline & Propionaldehyde & 4060 & & 10 \\
\hline & Crotonaldehyde & 1280 & & 10 \\
\hline & Methylethylketone & 4280 & & 10 \\
\hline & $n$-Butyraldehyde & 2010 & & 10 \\
\hline \multirow[t]{6}{*}{ Penolics } & Hydroquinone & 3226 & 2 & 11 \\
\hline & Resorcinol & 83.0 & & 11 \\
\hline & Catechol & 3921 & 3 & 11 \\
\hline & Phenol & 960 & & 11 \\
\hline & $m$ - and $p$-Cresol & 722 & & 11 \\
\hline & o-Cresol & 327 & & 11 \\
\hline \multirow[t]{4}{*}{ Aromatic amines } & 1-Aminonaphthalene & 1.16 & & 12 \\
\hline & 2-Aminonaphthalene & 0.788 & & 12 \\
\hline & 3-Aminobiphenyl & 0.188 & & 12 \\
\hline & 4-Aminobiphenyl & 0.130 & & 12 \\
\hline \multirow[t]{21}{*}{ Polycyclic aromatic hydrocarbons (PAH) } & Benzo[a]pyrene & 0.685 & & 13 \\
\hline & Benz[a]anthracene & 1.26 & & 13 \\
\hline & Dibenz $[a, h]$ anthracene & 0.136 & & 13 \\
\hline & Dibenzo[a,e]pyrene & 0.072 & & 13 \\
\hline & Dibenzo[a,h]pyrene & 0.118 & & 13 \\
\hline & Dibenzo[a,i]pyrene & 0.088 & & 13 \\
\hline & Dibenzo[a,/]pyrene & 0.034 & & 13 \\
\hline & Indeno[1,2,3-cd]pyrene & 0.301 & & 13 \\
\hline & Benzo[b]fluoranthene & 0.545 & & 13 \\
\hline & Benzo[j]fluoranthene & 0.311 & & 13 \\
\hline & Benzo[k]fluoranthene & 0.368 & & 13 \\
\hline & Naphthalene & 47.3 & & 13 \\
\hline & Acenaphthylene & 11.1 & & 13 \\
\hline & Acenaphthene & 3.74 & & 13 \\
\hline & Fluorene & 19.2 & & 13 \\
\hline & Phenanthrene & 15.7 & & 13 \\
\hline & Anthracene & 5.53 & & 13 \\
\hline & Fluoranthene & 6.14 & & 13 \\
\hline & Pyrene & 5.17 & & 13 \\
\hline & Chrysene & 1.62 & & 13 \\
\hline & Benzo[g,h,i]perylene & 0.222 & & 13 \\
\hline \multirow[t]{5}{*}{ Others } & Pyridine & 340 & 4 & \\
\hline & Quinoline & 24.0 & 5 & \\
\hline & Styrene & 145 & 6 & \\
\hline & Hydrogen cyanide & 4927 & 7 & \\
\hline & Nicotine & 71000 & 8 & \\
\hline
\end{tabular}

a) NNN: N-nitrosonornicotin; NAT: N-nitrosoanatabine; NAB: N-nitrosoanabasine; NNK: 4-methylnitrosoamino-1-(3-pyridyl)-1-butanone

\section{WST-1 assay}

A process identical to that of the NRU assay was carried out up to the point of dye addition. At this point in contrast to the NRU assay $200 \mu \mathrm{L}$ of medium including $0.33 \mathrm{mg} / \mathrm{mL}$ of WST-1 reagent (Dojindo Laboratories, Kumamoto, Japan) was added to the well. After incubation for 3 hours, the tissue culture plate was shaken at $800 \mathrm{rpm}$ for $10 \mathrm{~min}$. The absorbance was then measured at $450 \mathrm{~nm}$ using the microplate reader. 

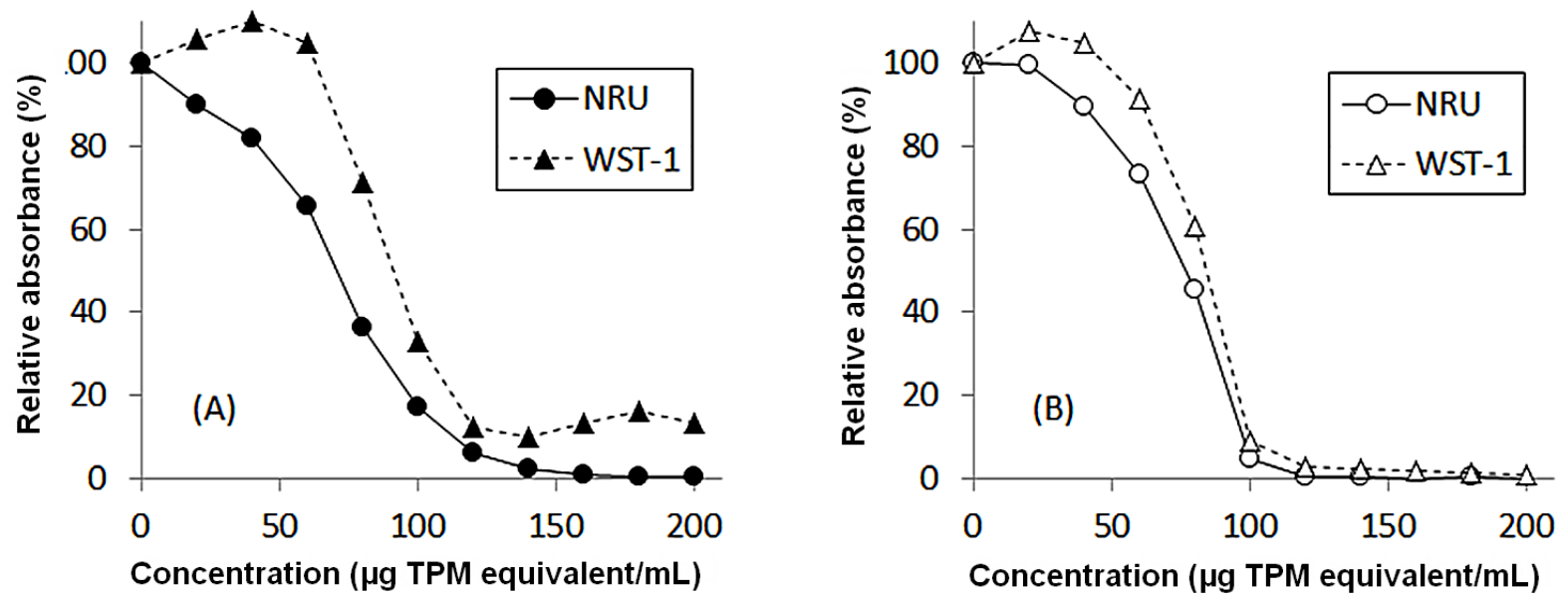

Figure 1. Dose response curve of TPM fraction (A) and GVP fraction (B) prepared from 3R4F cigarettes.

\section{Statistical analysis}

The degree of cytotoxicity was defined as the reciprocal of the $\mathrm{IC}_{50}$ value which is the $50 \%$ inhibitory concentration of neutral red uptake for the NRU assay or formazan formation for the WST-1 assay. Calculations were conducted using statistical software (JMP version 8.0, SAS Institute Japan, Tokyo, Japan).

To enable the estimation of the $\mathrm{IC}_{50}$, non-linear regression analysis for the relationship between relative absorbance and concentration was performed based on least squares methodology using a logistic function. From the dose-response curve the $\mathrm{IC}_{50}$ value was derived by inverse estimation as the effective concentration at which the absorbance was reduced by half of concurrent solvent control.

\section{RESULTS}

Cytotoxicity of cigarette smoke

The TPM and GVP fractions prepared from 3R4F and test cigarettes constructed of single tobacco types were applied in the NRU and WST-1 assay as a means to investigate the cigarette smoke cytotoxicities in different assays.

Smoke samples were applied separately to each assay in two separate experiments for ten TPM fractions and two for six GVP fractions. Duplicate assays were carried out for each sample. The dose response curves of the TPM and GVP fractions from 3R4F cigarettes are shown in Figure 1. Regarding the smoke samples from the other test cigarettes, the relative absorbance also clearly decreased in a dose-dependent manner in both assays (data not shown).

Table 3. $I_{50}$ values of cigarette smoke samples. Average of $I C_{50}$ values $(\mu \mathrm{g} / \mathrm{mL})$ produced from duplicates (for test cigarettes) or quadruplicates (for 3R4F).

\begin{tabular}{l|c|c|c|c}
\hline \multirow{2}{*}{ Cigarette code } & \multicolumn{2}{|c|}{ TPM fractions } & \multicolumn{2}{c}{ GVP fractions $^{\text {a) }}$} \\
\cline { 2 - 5 } & NRU assay & WST-1 assay & NRU assay & WST-1 assay \\
\hline FC-1 & 57.6 & 75.4 & 293.7 & 302.2 \\
FC-2 & 59.6 & 79.7 & - & - \\
FC-3 & 55.7 & 70.8 & 222.7 & 241.1 \\
FC-4 & 44.7 & 56.7 & 179.9 & - \\
FC-5 & 54.0 & 67.7 & - & 636.4 \\
BLY-1 & 103.2 & 124.4 & 460.3 & 404.6 \\
BYL-2 & 119.5 & 116.8 & 327.5 & 351.6 \\
BLY-3 & 66.6 & 76.4 & 300.7 & - \\
BLY-4 & 70.0 & 81.8 & - & - \\
BLY-5 & 66.4 & 74.8 & 98.2 & 111.2 \\
3R4F & 81.6 & 95.0 & & \\
\hline
\end{tabular}

a) - : not tested 

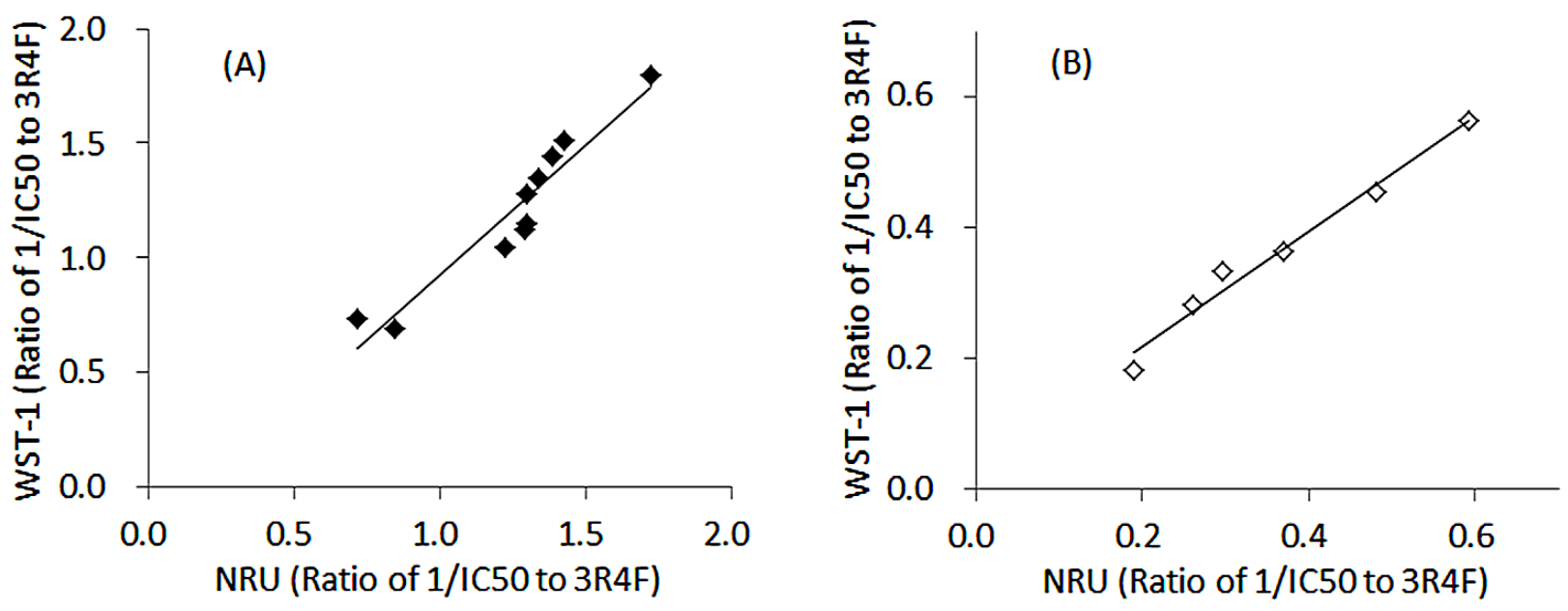

Figure 2. Correlation between cytotoxicities found in NRU and WST-1 assay. (A): TPM samples; (B): GVP samples.

In making a comparison between $\mathrm{IC}_{50}$ values calculated from the two assays for identical samples, the $\mathrm{IC}_{50}$ values in the NRU assay, with one exception, were always lower than that from the WST-1 assay (Table 3), that is, the NRU assay responds at lower concentration toward the damage of cell functions. However, in terms of the rank order of $\mathrm{IC}_{50}$ values among the samples tested, the two assays produced the same result i.e., both smoke fractions from flue-cured tobacco tended to be of higher cytotoxicity when compared with those from Burley tobacco. The comparative approach is important in evaluating the biological effects of smoke samples from different cigarette configurations. Namely, the interpretation of the relative effect between samples rather than the absolute value found in the assay is generally required for assessing smoke toxicity with in vitro biological tests. Therefore, the correlation analysis using magnitudes of cytotoxic responses exhibited in the two assays was performed to confirm the relative cytotoxicity among the smoke samples tested. For this analysis, in consideration of the possibility that cell sensitivity may be variable from trial to trial, the reciprocal of the $\mathrm{IC}_{50}$ value from the test cigarettes was normalized with data from the 3R4F cigarettes tested concurrently. The results of this analysis for the TPM and the GVP samples are shown in Figure 2; there was a good correlation $(r=0.957$ for the TPM and $r=0.989$ for the GVP) between the normalized values found in the NRU and the WST-1 assays. However, even without normalization to the $3 \mathrm{R} 4 \mathrm{~F}$ cigarettes, the correlation was rather tight $(r=0.957$ for the TPM and $r=0.986$ for the GVP).
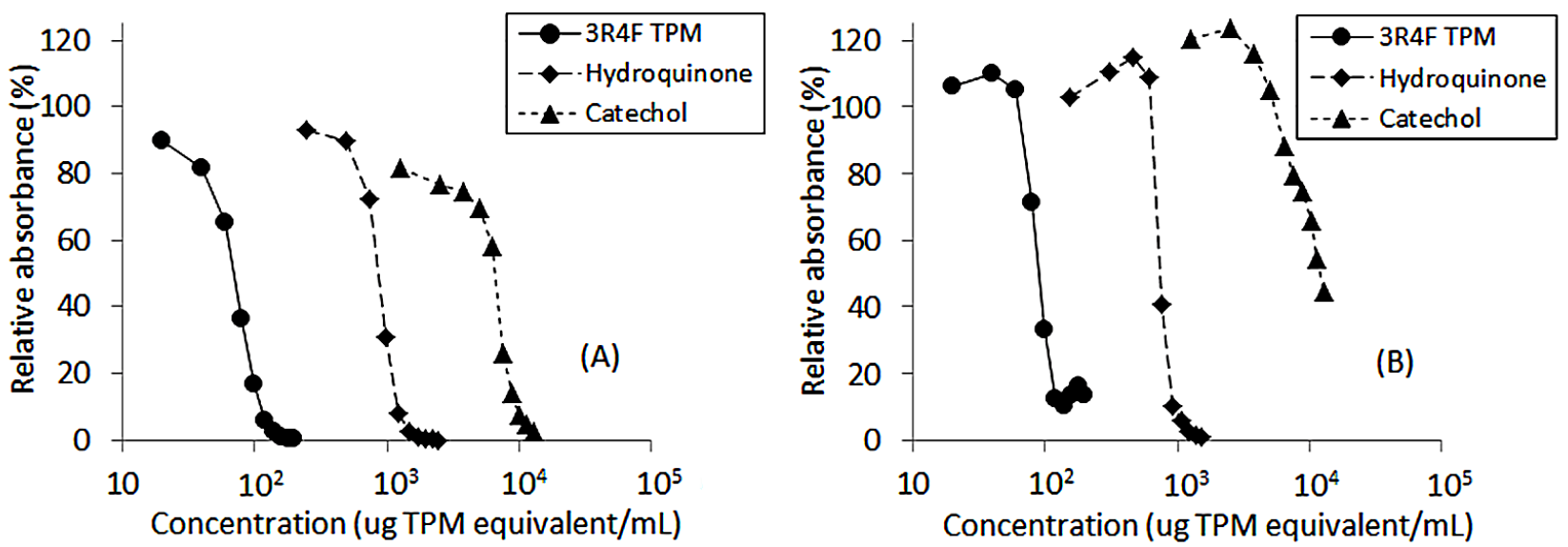

Figure 3. Dose response curve of 3R4F TPM and smoke constituents in TPM fraction with NRU assay (A) and WST-1 assay (B). Concentration was expressed on a unit of TPM equivalent weight basis. 

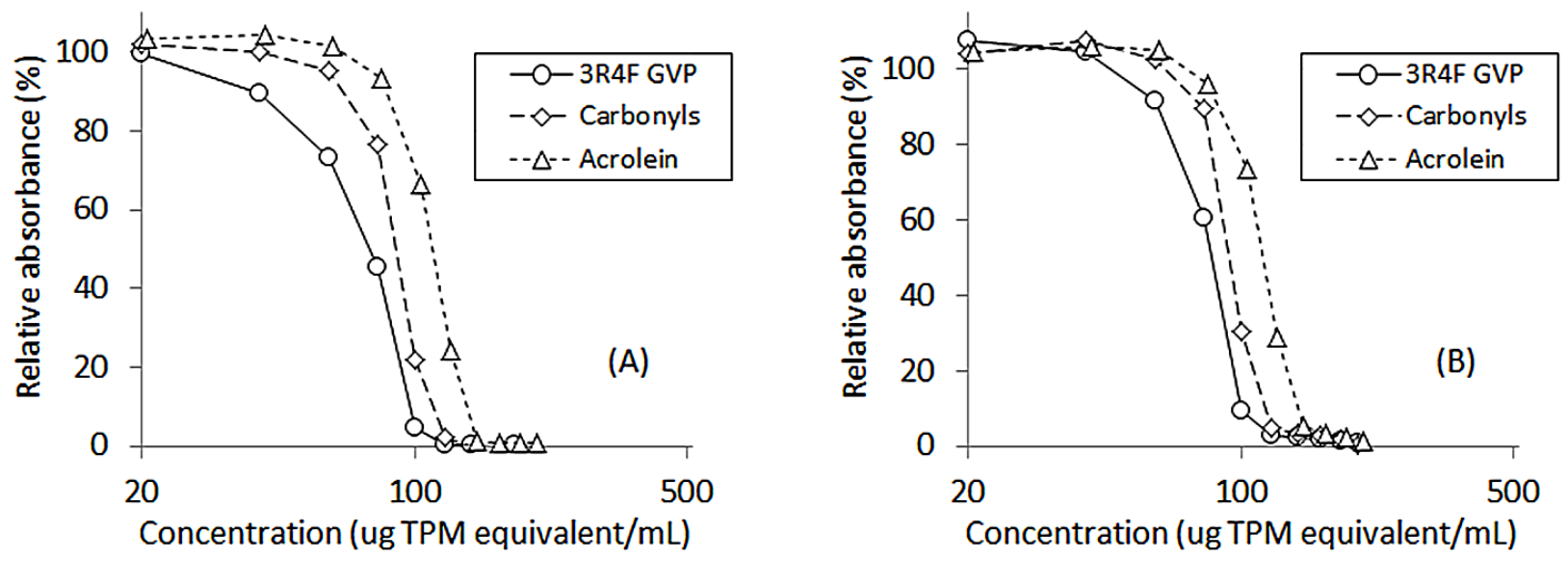

Figure 4. Dose response curve of 3R4F GVP and smoke constituents in GVP fraction with NRU assay (A) and WST-1 assay (B). Concentration was expressed as a unit of TPM equivalent weight basis.

\section{Cytotoxicity of smoke constituents}

The contribution of several smoke constituents to the cigarette smoke cytotoxicities was investigated in the two assays. Forty-eight chemicals that are toxicants and potential toxicants were selected for this experiment. Chemicals with similar structure were grouped, and DMSO solutions of 5 mixtures, tobacco-specific nitrosamines, carbonyls, phenolics, aromatic amines and polycyclic aromatic hydrocarbons as well as those of eight substances of different chemical classes were prepared for analysis in the assays (Table 2). The concentration of each chemical was interpreted as the equivalent weight of TPM, which was calculated on the amount of the constituent in the cigarette smoke from 3R4F. Nicotine was tested up to $8 \mathrm{mg}$ TPM equivalents per $\mathrm{mL}$. All other chemicals were tested up to $200 \mathrm{mg}$ TPM equivalents per $\mathrm{mL}$, i.e., the maximum doses that were more than 1000 times the concentration where the TPM and GVP samples from the 3R4F clearly indicated a response.

Acrolein, hydroquinone, catechol as well as the mixture of carbonyl and phenolic compounds showed a clear decrease of relative absorbance (Figure 3,4) in both assays, while TSNAs, aromatic amines and other constituents including nicotine did not give a cytotoxic response up to the maximum dose tested in this study (data not shown). The contribution rate of the smoke constituents to the cytotoxic potential of each smoke fraction was calculated for each assay. As the carbonyl compounds were included in the GVP fraction of the cigarette smoke, their contribution rates were calculated as the ratio of the reciprocal of the $\mathrm{IC}_{50}$ value to that of the GVP. The contribution of the mixture of eight carbonyl compounds to the GVP cytotoxicity was highest among the constituents tested and the rates were calculated to be $83.5 \%$ for the NRU assay and $88.1 \%$ for the WST-1 assay. Moreover, acrolein alone,

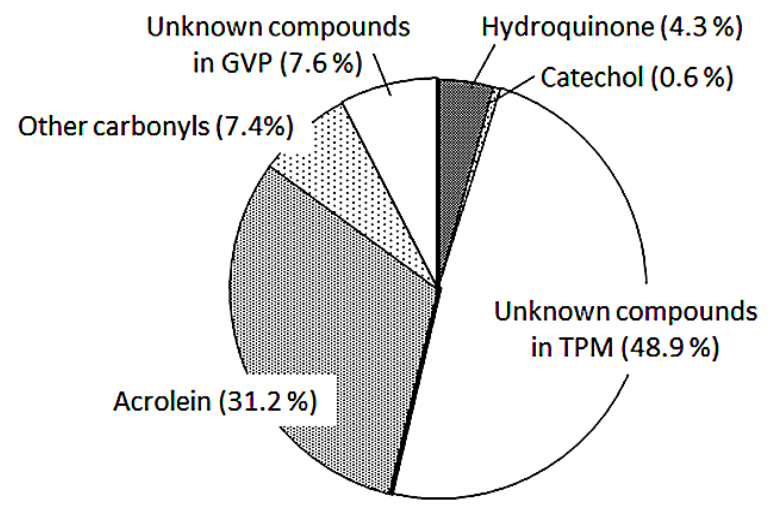

(A)

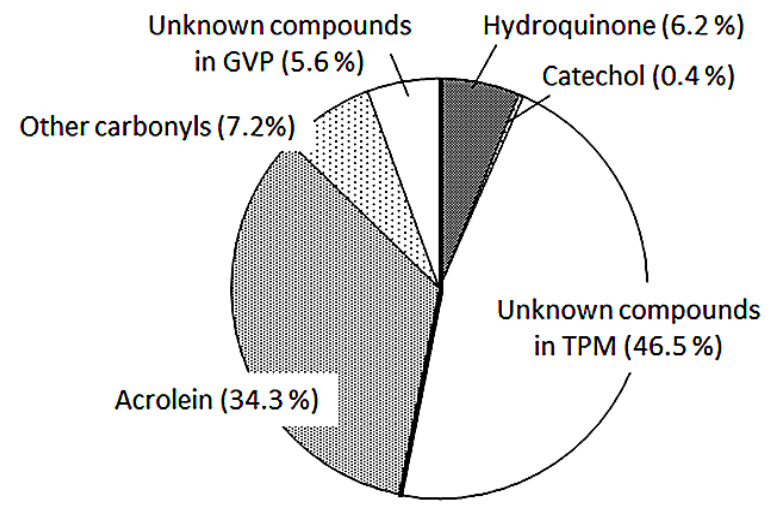

(B)

Figure 5. Contribution of smoke constituents to 3R4F mainstream smoke cytotoxicity found in NRU assay (A) and WST-1 assay (B). 

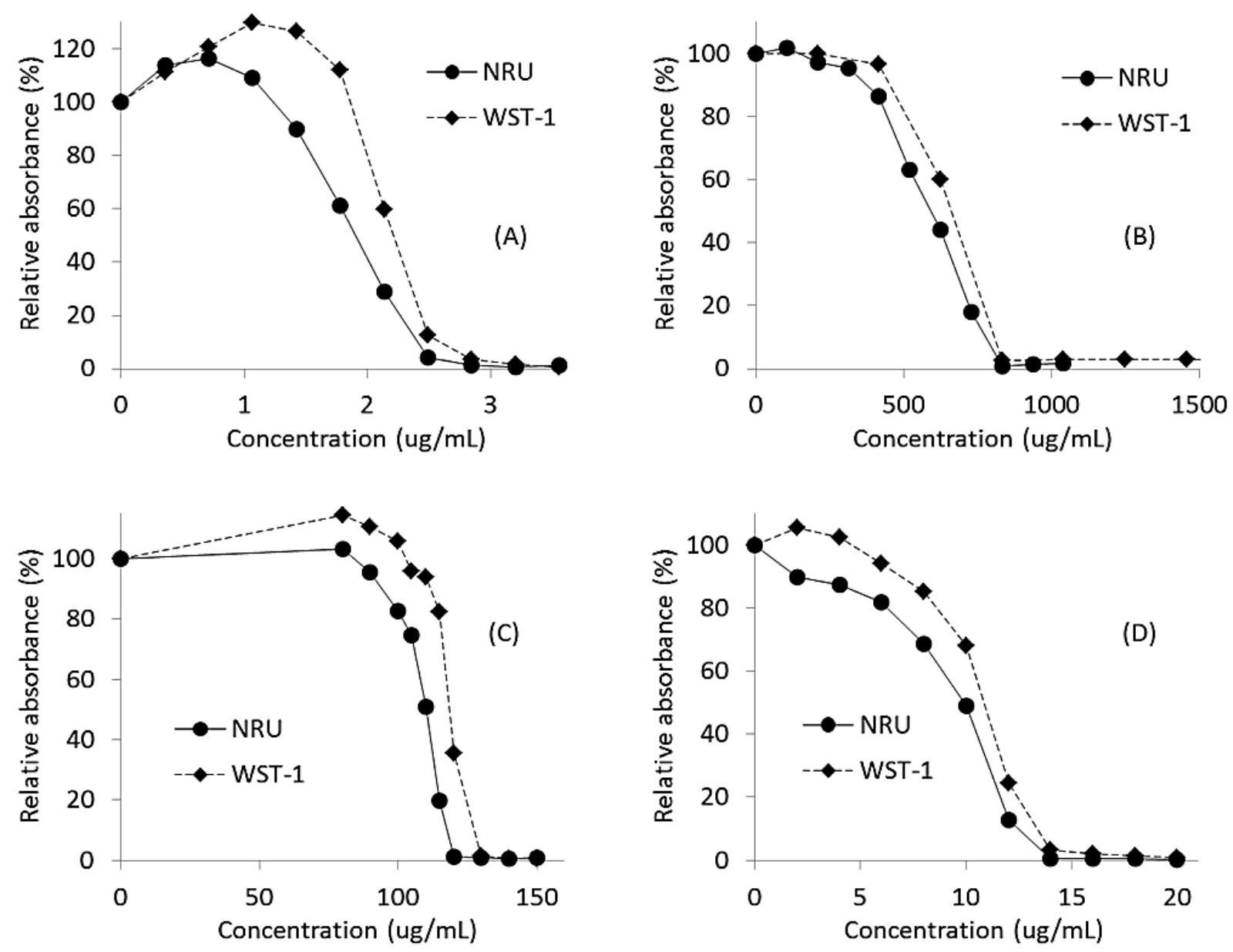

Figure 6. Dose response curve of chlorpromazine (A), malonic acid (B), sodium dodecyl sulfate (C), and benzethonium chloride (D) found in NRU assay and WST-1 assay.

a component of the carbonyl compounds was $67.6 \%$ for the NRU assay and $72.8 \%$ for the WST-1 assay. Meanwhile, hydroquinone and catechol included in the TPM fraction accounted for around $10 \%$ and $1 \%$ of the TPM cytotoxicity in both assays. In consideration of the ratio between the reciprocal of $\mathrm{IC}_{50}$ values from the TPM and the GVP, the contribution rates of tested constituents to the whole cigarette smoke cytotoxicities indicated on each assay were summarized in Figure 5. The two different assays showed nearly the same contribution rates of the smoke constituents to the cigarettes smoke cytotoxicity.

\section{Response to cytotoxic compounds}

As supplementary experiments, two types of reference cytotoxic chemicals that cause cellular damage by different mechanisms were examined in the NRU and WST-1 assays to investigate if the damage for the specific endpoint is reflected in the assay result. As shown in Figure 6, chlorpromazine and malonic acid that are mitochondrial enzyme inhibitors showed cytotoxic responses in the WST-1 assay as well as the NRU assay. The relative absorbance showed a decrease up to $3 \mu \mathrm{g} / \mathrm{mL}$ for chloropromazine and up to $1000 \mu \mathrm{g} / \mathrm{mL}$ for malonic acid in a dose-dependent manner. Sodium dodecyl sulfate (SDS) and benzethonium chloride known surfactants also gave a clear cytotoxic response in both assays. As was the case with the mitochondrial enzyme inhibitors, SDS and benzethonium chloride gave a clear dose response curve up to $150 \mu \mathrm{g} / \mathrm{mL}$ and $15 \mu \mathrm{g} / \mathrm{mL}$, respectively. There was little difference between the two assays in terms of concentration range exhibiting a dose response. The $\mathrm{IC}_{50}$ values found in both assays for each cytotoxic chemical are summarized in Table 4.

\section{DISCUSSION}

To ensure a better understanding of new cigarettes or those with a modified design, it is important to assess the biological effects of cigarette smoke using in vitro assays. To date, many in vitro cytotoxicity and genotoxicity assay systems have been established and validated to predict the potential effects in humans. While a single in vitro assay cannot provide sufficient toxicity information for all potential genotoxic and cytotoxic characteristics, it is considered that the results from an assessment using a battery of complementary in vitro tests are useful in 
Table 4. $I C_{50}$ value $(\mu \mathrm{g} / \mathrm{mL})$ of cytotoxic chemicals.

\begin{tabular}{lcc}
\hline & NRU assay & WST-1 assay \\
\hline Surfactant & & \\
SDS & 109 & 118 \\
Benzethonium chloride & 9.54 & 10.7 \\
$\begin{array}{l}\text { Mitochondrial enzyme } \\
\text { inhibitor }\end{array}$ & & \\
Chlorpromazine & 1.84 & 2.19 \\
Malonic acid & 0.586 & 0.642 \\
\hline
\end{tabular}

providing increased confidence in toxicological properties. The evaluation of genotoxicity for predicting the carcinogenic and tumorigenic potential of test materials is commonly assessed with a combination of in vitro assays which detect two endpoints using a bacterial gene mutation test and a mammalian cell test for cytogenetics, e.g., micronucleus assay, chromosome aberration assay, mouse lymphoma assay (24).

Meanwhile, with respect to cytotoxicity which may be useful for predicting processes such as irritation, inflammation, cell hyperplasia etc. in several chronic diseases, there are various tests which measure cell damage based on specific cell functions such as membrane integrity, cellular metabolism, mitochondrial activity and total protein synthesis or cell proliferation. Therefore, when choosing a cytotoxicity assay or considering a combination of assays, it is important to understand their characteristics. BORENFREUND et al. compared the NRU and MTT assays using $\mathrm{BALB} / \mathrm{c} 3 \mathrm{~T} 3$ cells in terms of the cytotoxic responses for 28 test agents, and concluded that although each test measures a different physiological endpoint, there was good agreement $(\mathrm{r}=0.939)$ between the rankings of agents for a majority of the $\mathrm{IC}_{50}$ values (34). WEYERMANN et al. investigated four cytotoxicity assays, lactate dehydrogenase (LDH) release, MTT formation, NRU and ATP content using infected mouse Ltk-cells (35). As a result of the evaluation of four chemicals that cause cell damage by different mechanisms, they did not find a consistent ranking of the $\mathrm{IC}_{50}$ values. It was concluded that the difference in the viability of the treated cells depended on the test agent and the assay used.

In the present study, it was found that the dose response decrease of absorbance from the NRU assay was generally observed to indicate slightly lower concentrations than in the WST-1 assay, and it followed that the $\mathrm{IC}_{50}$ value expressed with the WST-1 was relatively large. With respect to the response shown in the WST-1 assay, formazan production increased with exposure at low concentrations where little variation in the relative absorbance was observed in the NRU assay. A similar trend has been documented in previous literature for the MTT assay which has the same detection mechanism as the WST-1 assay $(35,36)$. We postulate that it is the intact enzymatic activity of surviving cells that compensates any effects by the test samples which could cause any cell damage, and consequently $\mathrm{IC}_{50}$ values would be relatively large in the WST-1 assay. For the toxicological assessment of cigarette products it is important to evaluate the relative toxicity between cigarette smoke samples from different configurations/specifications (e.g., with and without ingredients, before and after changing cigarette designs), rather than the absolute $\mathrm{IC}_{50}$ value from each sample. Therefore, the correlation analysis on the basis of $\mathrm{IC}_{50}$ values calculated from each assay was performed using samples prepared from different cigarettes. This result revealed that there was good agreement in the relative cytotoxicities, i.e., ranking of samples, although there were differences in absolute $\mathrm{IC}_{50}$ values between the two assays. A total of ten test cigarettes comprised of single grade tobaccos, i.e., five flue-cured and five Burley cigarettes, were produced and used for the present study. The cytotoxicities of smoke samples from the flue-cured type tended to yield greater degree of cytotoxicity than those of the Burley type, which was in accordance with a previous report (9). Moreover, when compared within the same type cigarettes, i.e., flue-cured or Burley, the cytotoxicities were also differentiated among the tobacco grades and the rankings of the smoke samples were nearly comparable between the NRU and WST-1 assay. It is thought that the difference in cytotoxicity was caused by the chemical composition of smoke samples. Although the ultimate constituents accounting for cigarette smoke cytotoxicity is less well known, it has been reported that phenolic compounds (e.g., hydroquinone, catechol) in TPM and carbonyl compounds (e.g., acrolein, acetaldehyde) in GVP showed a certain level of cytotoxicity $(37,38)$. Based on the results of the present study and Hoffmann analysis (data not shown), it was found that the cytotoxicity of TPM and GVP samples correlated with the amount of catechol $(r=$ 0.786 for NRU assay and $\mathrm{r}=0.877$ for WST- 1 assay) and acrolein $(r=0.978$ for NRU assay and $r=0.995$ for WST- 1 assay), respectively.

On the basis of smoke constituents, the contribution rates of each constituent to the cigarette smoke cytotoxicity exhibited by the WST-1 assay were comparable to those observed in the NRU assay. Moreover, in the experiment using two types of cytotoxic chemicals which cause cellular damage by different mechanisms, there was very little difference between the two assays in terms of concentration range exhibiting a dose response. Thus, we concluded that there is no clear advantage of assessing with a combination of the NRU and WST-1 assays under the conditions applied in this study.

The findings in this study were provided under limited conditions, e.g., exposure time for 24 hours, the use of CHO-K1 cells and the specific cell density for the exposure. Under the conditions of long-term exposure, the assays in this study are likely to be measuring the sum of all modes of cell death, encompassing both early and late events. PUTNAM et al. investigated the sensitivity of eight assays including the NRU and MTT to cigarette smoke condensate from the Kentucky reference 1R4F (35). They concluded that the sensitivity varied in accordance with time and endpoint measured. Cigarette smoke includes various cytotoxic compounds which act on different organelles and cell functions. Any of the toxic substances in cigarette smoke are known to act at an early stage (39-41). Since the test substances were evaluated at a single point of 24-hour exposure time in the present study, there is the possibility that the conclusion from a comparative assessment may not be in agreement between 
assay systems for a shorter exposure time. Moreover, there are a variety of cell lines which are commonly used for in vitro toxicological assays which may also introduce differences. Indeed, FOTAKIS et al. reported that there are differences between the cell lines regarding their sensitivity to cadmium chloride due to the differences in their uptake mechanisms (42). Therefore, further studies to investigate the effects of different assay conditions such as the exposure time or cell line on relative cytotoxicity may be needed to further clarify the advantage of a combinational assessment using complementary cytotoxicity assays.

\section{REFERENCES}

1. International Agency for Research on Cancer (IARC): Tobacco Smoke and Involuntary Smoking; IARC Monographs on the Evaluation of the Carcinogenic Risks of Chemicals to Humans, Vol. 83, IARC, Lyon, France, 2004.

2. US Department of Health and Human Service: The Health Consequences of Smoking: A Report of the Surgeon General; (2004) Department of Health and Human Services, Centers for Disease Control and Prevention, National Center for Chronic Disease Prevention and Health Promotion, Office on Smoking and Health, Washington DC, USA; available at: http://www.cdc.gov/tobacco/data_statistics/sgr/2004/ index.htm (Accessed September 2014).

3. Thun, M.J.: Tobacco Use and Cancer: An Epidemiologic Perspective; in: Alcohol, Tobacco and Cancer; edited by C.H. Cho and V. Purohit, Karger AG, Basel, Switzerland, 2006, pp. 189-204.

4. Halle, W. and H. Spielmann: Two Procedures for the Prediction of Acute Toxicity $\left(\mathrm{LD}_{50}\right)$ From Cytotoxicity Data; ATLA 20 (1992) 40-49.

5. Shrivastava, R., C. Delomenie, A. Chevalier, G. John, B. Ekwall, E. Walum, and R. Massingham: Comparison of In Vivo Acute Lethal Potency and In Vitro Cytotoxicity of 48 Chemicals; Cell Biol. Toxicol. 8 (1992) 157-170.

6. Ekwall, B.: Overview of the Final MEIC Results: II. The In Vitro -- In Vivo Evaluation, Including the Selection of A Practical Battery of Cell Tests for Prediction of Acute Lethal Blood Concentrations in Humans; Toxicol. In Vitro 13 (1999) 665-673.

7. National Institute of Environmental Health Sciences: Guidance Document on Using In Vitro Data to Estimate In Vitro Starting Doses for Acute Toxicity; NIH Publication No. 01-4500 (2001) National Toxicology Program, National Institutes of Health, US Public Health Service and US Department of Health and Human Services NC, USA; available at: http://www. epa.gov/hpv/pubs/general/nih2001b.pdf. (Assessed September 2014).

8. Klimisch, H.J. and W. Dontenwill: Investigations of Cigarette Smoke Dosages in Inhalation Experiments with Syrian Hamsters. I. Concentration of Cigarette Smoke in the Inhalation Chamber and of Carbon Monoxide in the Blood; J Nat. Cancer Inst. 58 (1977) 931-933.

9. Bombick, D.W., K. Putnam, and D.J. Doolittle:
Comparative Cytotoxicity Studies of Smoke Condensates From Different Types of Cigarettes and Tobaccos; Toxicol. In Vitro 12 (1998) 241-249.

10. Andreoli, C., D. Gigante, and A. Nunziata: A Review of In Vitro Methods to Assess the Biological Activity of Tobacco Smoke with the Aim of Reducing the Toxicity of Smoke; Toxicol. In Vitro 17 (2003) 587-594.

11. Life Science Research Office (LSRO): Biological Effects Assessment in the Evaluation of Potential Reduced-Risk Tobacco Products; edited by A.M. Brownawell, LSRO, Bethesda, Maryland, USA, 2007.

12. Rodgman, A. and T.A. Perfetti: The Chemical Components of Tobacco and Tobacco Smoke, 2nd Edition; CRC press, Boca Raton, Florida, USA, 2013.

13. Perfetti, T.A. and A. Rodgman: The Complexity of Tobacco and Tobacco Smoke; Beitr. Tabakforsch. Int. 24 (2011) 215-232.

14. DeMarini, D.M.: Genotoxicity of Tobacco Smoke and Tobacco Smoke Condensate: A Review; Mutat. Res. 567 (2004) 447-474.

15. Johnson, M.D., J. Schilz, M.V. Djordjevic, J.R. Rice, and P.G. Shields: Evaluation of In Vitro Assays for Assessing the Toxicity of Cigarette Smoke and Smokeless Tobacco; Cancer Epidemiol. Biomarkers Prev. 18 (2009) 3263-3304.

16. Adamson, J., L.E. Haswell, G. Phillips, and M.D. Gaça: In Vitro Models of Chronic Obstructive Pulmonary Disease (COPD); in: Bronchitis, edited by I. Martin-Loeches, InTech, Rijeka, Croatia, 2011.

17. Fearon I.M., M.D. Gaça, and B.K. Nordskog: In Vitro Models for Assessing the Potential Cardiovascular Disease Risk Associated with Cigarette Smoking; Toxicol. In Vitro 27 (2013) 513-522.

18. Bombick, B.R., H. Murli, J.T. Avalos, D.W. Bombick, W.T. Morgan, K.P. Putnam, and D.J. Doolittle: Chemical and Biological Studies of A New Cigarette That Primarily Heats Tobacco. Part 2. In Vitro Toxicology of Mainstream Smoke Condensate; Food Chem. Toxicol. 36 (1998) 183-90.

19. DeMarini, D.M., R. Gudi, A. Szkudlinska, M. Rao, L. Recio, M. Kehl, P.E. Kirby, G. Polzin, and P.A. Richter: Genotoxicity of 10 Cigarette Smoke Condensates in Four Test Systems: Comparisons Between Assays and Condensates; Mutat. Res. 650 (2008) 15-29.

20. Gaworski, C.L., H. Schramke, J. Diekmann, T.J. Meisgen, F.J. Tewes, D.J. Veltel, P.M. Vanscheeuwijck, N. Rajendran, M. Muzzio, and H.J. Haussmann: Effect of Filtration by Activated Charcoal on the Toxicological Activity of Cigarette Mainstream Smoke From Experimental Cigarettes; Inhal. Toxicol. 21 (2009) 688-704.

21. Combes, R., K. Scott, D. Dillon, C. Meredith, K. McAdam, and C. Proctor: The Effect of A Novel Tobacco Process on the In Vitro Cytotoxicity and Genotoxicity of Cigarette Smoke Particulate Matter; Toxicol. In vitro 26 (2012) 1022-1029.

22. CORESTA In Vitro Toxicology Task Force: The Rationale and Strategy for Conducting In Vitro Toxicology Testing of Tobacco Smoke; CORESTA Reports, Paris, France, 2014; available at: http://www. coresta.org/Reports/IVT_TF_Rationale-IVT-Testing- 
Tob.-Smoke_Report_Jun04.pdf (Assessed September 2014) .

23. Ishiyama, M., H. Tominaga, M. Shiga, K. Sasamoto, Y. Ohkura, and K. Ueno: A Combined Assay of Cell Viability and In Vitro Cytotoxicity with a Highly Water-Soluble Tetrazolium Salt, Neutral Red and Crystal Violet; Biol. Pharm. Bull. 19 (1996) 1518-1520.

24. International Conference on Harmonisation of Technical Requirements for Registration of Pharmaceuticals for Human Use (ICH): Guidance on Genotoxicity and Data Interpretation for Pharmaceuticals Intended for Human Use S2(R1); ICH Harmonised Tripartite Guideline, 2011; available at: http://www.ich.org/fileadmin/Public_Web_Site/ ICH_Products/Guidelines/Safety/S2_R1/Step4/S'RR1_ Step4.pdf (Assessed September 2014).

25. Borenfreund, E. and J.A. Puerner: A Simple Quantitative Procedure Using Monolayer Cultures for Cytotoxicity Assays (HTD/NR-90); J. Tissue Cult. Methods 9 (1985), 7-9.

26. Ishiyama, M., M. Shiga, K. Sasamoto, M. Mizoguchi, and P.G. He: A New Sulfonated Tetrazolium Salt That Produces A Highly Water-soluble Formazan Dye; Chem. Pharm. Bull. 41 (1993) 1118-1122.

27. International Organization for Standardization (ISO) ISO 3402. Tobacco and Tobacco Products Atmosphere for Conditioning and Testing; ISO, Geneva, Switzerland, 1999.

28. International Organization for Standardization (ISO): ISO 3308. Routine Analytical Cigarette Smoking Machine - Definitions and Standard Conditions. ISO, Geneva, Switzerland, 2000.

29. Health Canada: Health Canada Tobacco Reporting Regulations; Health Canada, Ontario, Canada, 2005 available at: http://www.hc-sc.gc.ca/hc-ps/tobactabac/legislation/reg/indust/method/index-eng.php \#main (Assessed September 2014).

30. Food and Drug Administration: Harmful and Potentially Harmful Constituents in Tobacco Products and Tobacco Smoke - Established List; Federal Register Vol. 77, Docket No. FDA-2012-N-0143, FDA, Maryland, USA, 2012, pp. 20034-37.

31. Slater, T.F., B. Sawyer, and U. Straeuli: Studies on Succinate-Tetrazolium Reductase Systems. III. Points of Coupling of Four Different Tetrazolium Salts; Biochim. Biophys. Acta. 77 (1963) 383-393.

32. Berridge, M.V. and A.S. Tan: Characterization of the Cellular Reduction of 3-(4,5-dimethylthiazol-2-yl)2,5-diphenyltetrazolium bromide (MTT): Subcellular Localization, Substrate Dependence, and Involvement of Mitochondrial Electron Transport in MTT Reduction; Arch. Biochem. Biophys. 303 (1993) 474-482.

33. Arechabala, B., C. Coiffard, P. Rivalland, L.J. Coiffard, and Y. de Roeck-Holtzhauer: Comparison of Cytotoxicity of Various Surfactants Tested on Normal Human Fibroblast Cultures Using the Neutral Red Test, MTT Assay and LDH Release; J. Appl. Toxicol. 19 (1999) 163-165.

34. Borenfreund, E., H. Babich, N. Martin-Alguacil: Comparisons of Two In Vitro Cytotoxicity Assays - The Neutral Red (NR) and Tetrazolium MTT Tests; Toxicol. In Vitro 2 (1988) 1-6.

35. Weyermann, J., D. Lochmann, and A. Zimmer: A Practical Note on the Use of Cytotoxicity Assays; Int. J. Pharm. 20 (2005) 369-376.

36. Putnam, K.P., D.W. Bombick, and D.J. Doolittle: Evaluation of Eight In Vitro Assays for Assessing the Cytotoxicity of Cigarette Smoke Condensate; Toxicol. In Vitro 16 (2002) 599-607.

37. Bombick, D.W. and D.J. Doolittle: The Role of Chemical Structure and Cell Type in the Cytotoxicity of Low Molecular Weight Aldehydes and Pyridines; In Vitro Toxicol. 8 (1995) 349-356.

38. Tewes, F.J., T.J. Meisgen, D.J. Veltel, E. Roemer, and G. Patskan; Toxicological Evaluation of An Electrically Heated Cigarette. Part 3: Genotoxicity and Cytotoxicity of Mainstream Smoke; J. Appl. Toxicol. 23 (2003) 341-348.

39. Aoshiba, K. and A. Nagai: Oxidative Stress, Cell Death, and Other Damage to Alveolar Epithelial Cells Induced by Cigarette Smoke; Tob. Induc. Dis. 1 (2003) 219-26.

40. Grafström, R.C., J.M. Dypbukt, J.C. Willey, K. Sundqvist, C. Edman, L. Atzori, and C.C. Harris: Pathobiological Effects of Acrolein in Cultured Human Bronchial Epithelial Cells; Cancer Res. 48 (1988) 1717-1721.

41. Chouchane, S., J.B. Wooten, F.J. Tewes, A. Wittig, B.P. Müller, D. Veltel, and J. Diekmann: Involvement of Semiquinone Radicals in the In Vitro Cytotoxicity of Cigarette Mainstream Smoke; Chem. Res. Toxicol. 19 (2006) 1602-1610.

42. Fotakis, G. and J.A. Timbrell: In Vitro Cytotoxicity Assays: Comparison of LDH, Neutral Red, MTT and Protein Assay in Hepatoma Cell Lines Following Exposure to Cadmium Chloride; Toxicol. Lett. 160 (2006) 171-177.

\section{Corresponding author:}

Toshiro Fukushima

Product Science Division

Japan Tobacco Inc.

6-2 Umegaoka, Aoba-ku, Yokohama, Kanagawa 227-8512

Japan

toshiro.fukushima@jt.com 